\title{
Waardenburg Syndrome Type I
}

\section{Vykuntaraju K. Gowda ${ }^{1,2}$ (D) Sahana Srinivas ${ }^{3}$ - Varunvenkat M. Srinivasan ${ }^{4}$}

Received: 13 September 2019 / Accepted: 23 December 2019 / Published online: 27 January 2020

(C) Dr. K C Chaudhuri Foundation 2020

Waardenburg Syndrome Type I (WS) is a rare genetic disorder, with pigmentary anomalies of eyes, skin and deafness [1]. A 5-y-old girl born at term, of non-consanguineous marriage presented with inability to hear and speak since birth. Both parents were deaf. Other developmental milestones were normal. Examination revealed white forelock, heterochromia iridium, dystopia canthorum (Fig. 1A), and depigmented macules over dorsum of hand and legs (Fig. 1B). No waveforms were noted in brain stem auditory evoked potentials, suggesting bilateral auditory pathway dysfunction.

The four types of WS are distinguished by their physical characteristics [2]. Dystopia canthorum is common in type I and hearing loss occurs more often in type II. Type III includes limb abnormality and Type IV is associated with Hirschsprung disease. We diagnosed WS type I based on clinical criteria. Differentials include piebaldism which has islands of increased pigmentation in the hypomelanotic areas and sometimes with hyperpigmented borders. Early diagnosis and management of deafness in Waardenburg syndrome improves the quality of life.

Vykuntaraju K. Gowda

drknvraju08@gmail.com

1 Division of Pediatric Neurology, Department of Pediatrics, Indira Gandhi Institute of Child Health, Bangalore, India

2 Bangalore Child Neurology and Rehabilitation Center, \#8/A, First main, First Cross, Vijayanagar, Bangalore 560040, India

3 Department of Pediatric Dermatology, Indira Gandhi Institute of Child Health, Bangalore, India

4 Department of Pediatrics, Indira Gandhi Institute of Child Health, Bangalore, India

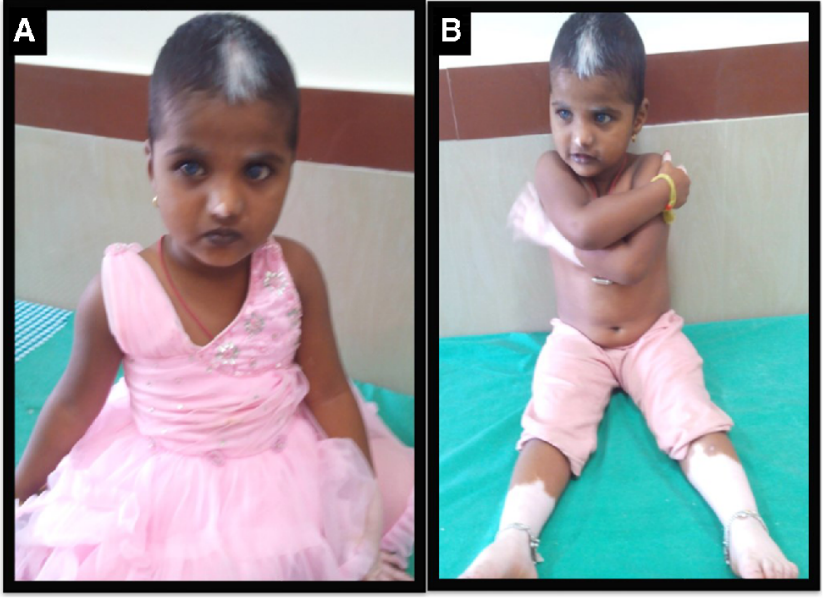

Fig. 1 Photograph of the child showing (A) white forelock on the frontal region of scalp along with heterochromia irides and (B) a well defined depigmented macule present bilaterally, symmetrical on the hands extending to mid forearm and bilateral feet extending on to both lower legs

\section{Compliance with Ethical Standards}

Conflict of Interest None.

\section{References}

1. Tagra S, Talwar AK, Walia RL, et al. Waardenburg syndrome. Indian J Dermatol Venereal Leprol. 2006;72:326.

2. Milunsky JM. Waardenburg syndrome type I. In: Pagon RA, Adam MP, Ardinger HH, et al., editors. Gene Reviews. Seattle (WA): University of Washington, Seattle: 1993-2014;2001.

Publisher's Note Springer Nature remains neutral with regard to jurisdictional claims in published maps and institutional affiliations. 